\title{
'Candidatus Phytoplasma americanum', a phytoplasma associated with a potato purple top wilt disease complex
}

\author{
Correspondence \\ Ing-Ming Lee \\ leeim@ba.ars.usda.gov
}

\author{
Ing-Ming Lee, ${ }^{1}$ Kristi D. Bottner, ${ }^{1}$ Gary Secor ${ }^{2}$ and Viviana Rivera-Varas ${ }^{2}$ \\ ${ }^{1}$ Molecular Plant Pathology Laboratory, USDA, ARS, Beltsville, MD 20705, USA \\ ${ }^{2}$ Department of Plant Pathology, North Dakota State University, Fargo, ND 58105, USA
}

Phytoplasmas are unculturable plant-pathogenic, wall-less bacteria (mollicutes) that cause diseases in several hundred plant species worldwide (McCoy et al., 1989). Phytoplasmas constitute a large, genetically diverse group. Currently, 17 groups and more than 40 subgroups have been classified based on RFLP analysis of 16S rRNA gene sequences and 24 'Candidatus Phytoplasma' species have been proposed (Arocha et al., 2005; IRPCM, 2004; Lee et al., 2000; Valiunas et al., 2006). At least four distinct phytoplasma strains have been associated with diseases of potato (Solanum tuberosum), including two major diseases, potato witches'-broom (PWB) and potato purple top wilt (PPT), which occur in North America and Mexico (Banttari et al., 1990; Khadhair et al., 1997; Lee et al., 2000, 2004a; Leyva-López et al., 2002). PWB disease is attributed to a phytoplasma strain belonging to the clover proliferation group (16SrVI group) subgroup 16SrVI-A, whereas PPT disease is associated with three phytoplasma strains belonging to aster yellows group

Abbreviations: APPTW, American potato purple top wilt; IBS, bindweed yellows phytoplasma; PPT, potato purple top wilt; PWB, potato witches'broom.

The GenBank/EMBL/DDBJ accession number for the 16S rRNA gene sequence of 'Candidatus Phytoplasma americanum' strain APPTW12$\mathrm{NE}$ is DQ174122.
(16SrI) subgroup $16 \mathrm{SrI}-\mathrm{B}$, peanut witches'-broom group (16SrII) and subgroup 16SrVI-A.

In 2004 and 2005, an outbreak of a new disease of potato occurred in Texas and Nebraska, USA, which caused darkening of potato chips (potato crisps) produced from infected tubers. This chip defect has resulted in a considerable economic loss in the local potato industry. Infected potato plants exhibited symptoms similar to those of the PPT disease recently found in Washington and Oregon, USA, which is caused by a subgroup 16SrVI-A phytoplasma (Lee et al., 2004a). Symptoms included stunting, chlorosis, slight purple discoloration of new growth, leaf curl, swollen nodes, broken axillary buds and the formation of aerial tubers. Storage tubers from affected plants either did not sprout or produced spindle or hair sprouts. Preliminary RFLP and sequence analysis of PCR-amplified 16S rRNA gene sequences indicated that two different phytoplasmas were associated with this PPT disease complex (Secor et al., 2006). One phytoplasma was classified as belonging to group 16SrI-A, while the other was identified as a novel phytoplasma distinct from PPT phytoplasmas described elsewhere and taxonomically distinct from previously described 'Candidatus Phytoplasma' species. In this communication, we propose that the newly recognized phytoplasma 
associated with PPT syndrome in Texas and Nebraska, USA, be considered as a novel 'Candidatus Phytoplasma' species.

More than 30 samples of leaf or stolon tissue were collected from potato fields in Nebraska and Texas and from more than 20 tuber samples exhibiting chip darkening in commercial storage in Texas. Cultivars tested included Atlantic, Snowden and FL1833. Total nucleic acid was extracted from leaf veinal tissue, stolons and tubers of symptomatic plants according to a modified procedure using the DNeasy Plant Mini kit (Qiagen) as described by Green et al. (1999). Veinal tissue collected from symptomatic plants exhibiting both leaf curl and swollen bud proliferation was more suitable for phytoplasma DNA extraction. Nested PCRs using universal primer pair P1/P7 or P1/16S-SR (Lee et al., 2004b; Schneider et al., 1995) followed by primers R16F2n/R16R2n were performed as described previously (Lee et al., 1998) to detect the presence of phytoplasmas in the samples. Products from nested PCR were analysed by single-enzyme digestion with AluI, MseI, TaqI, Tsp509I and three additional enzymes, BfaI, HaeIII and ThaI (data not shown). The resulting RFLP patterns were compared with those described previously (Lee et al., 1998). Stolbur-Rus (16SrXII-A) and PPT8-WA (16SrVI-A) were used as reference strains (Fig. 1). StolburRus is a stolbur phytoplasma previously detected in an infected potato plant in Russia. PPT8-WA was previously detected in a PPT-infected potato in Washington State,
USA (Lee et al., 2004a). Maps of putative restriction sites (Fig. 2) were constructed by using the LASERGENE software MapDraw program (DNAStar). Alignments of sequences were carried out and the sequence similarities calculated by the MegAlign program from the LASERGENE software suite. To obtain nearly full-length $16 \mathrm{~S}$ rRNA gene sequences, diluted P1/P7 or P1/16S-SR PCR products $(1: 30$ in sterile water) were reamplified using the primer pair P1A/16S-SR, as previously described (Lee et al., 2004b). The resulting products were purified using PCR Kleen spin columns (BioRad) and cloned into Escherichia coli using the TOPO-TA cloning kit (Invitrogen) according to the manufacturers' instructions. Sequencing was performed using an automated DNA sequencer (ABI 3100). Sequences were deposited in GenBank and accession numbers are given in Fig. 3. Other sequences used in this study were obtained from GenBank. Phylogenetic interrelationships among the novel PPT phytoplasma strains and strains representing all previously described phytoplasma groups were assessed on the basis of analysis of $16 \mathrm{~S}$ rRNA gene sequences. 16S rRNA gene sequences derived from the novel PPT phytoplasmas from Texas and Nebraska (this study), along with 21 'Candidatus Phytoplasma' species, other phytoplasma strains and Acholeplasma palmae ATCC $49389^{\mathrm{T}}$ were aligned using CLUSTAL V (Higgins \& Sharp, 1989) from the LASERGENE software MegAlign program. Cladistic analyses were performed using PAUP version 4.0 (a)
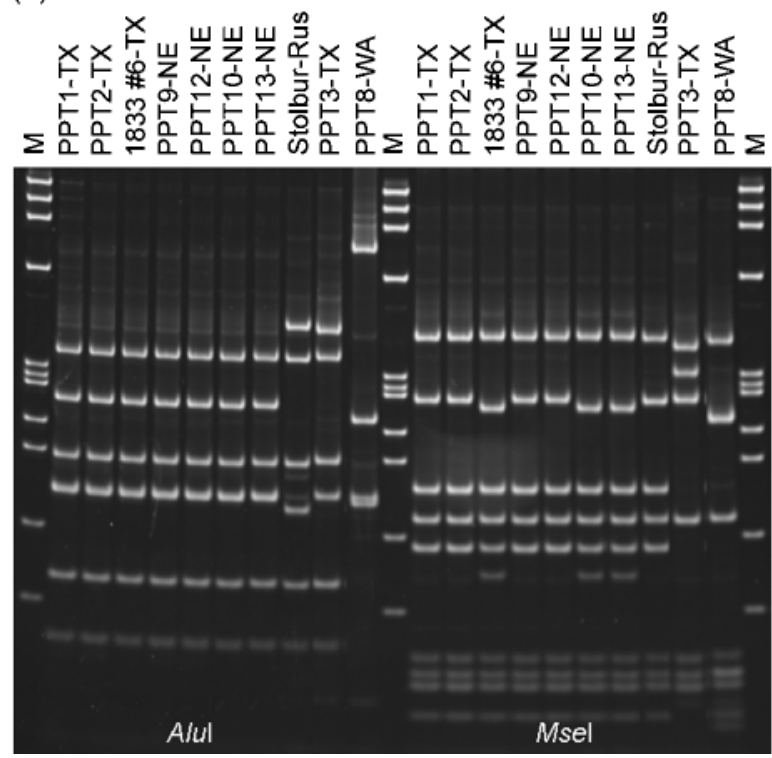

(b)
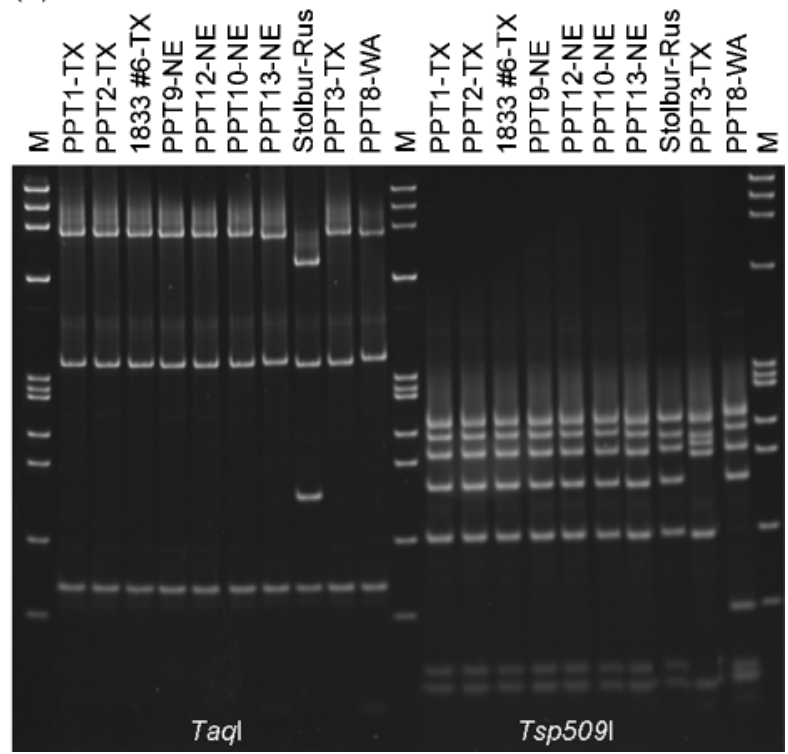

Fig. 1. RFLP profiles of $1 \cdot 2 \mathrm{~kb}$ of the $16 \mathrm{~S}$ rRNA gene amplified by nested PCR using primer pair P1/16S-SR followed by primer pair R16F2n/R16R2n from representative phytoplasma strains detected in potato plants with PPT symptoms in Texas (TX) and Nebraska (NE). A strain of stolbur phytoplasma (Stolbur-Rus, 16SrXII-A) and a strain of PPT phytoplasma (PPT8WA, 16SrVI-A) associated with PPT-infected potato plants in Washington State, USA, are the reference strains used for comparison. PCR products were digested with restriction enzymes Alul and Msel (a) and Taql and Tsp509l (b) and separated by electrophoresis through $5 \%$ polyacrylamide gels. $\mathrm{M}, \phi \mathrm{X} 174$ replicating form I DNA Haell digest, fragment sizes (bp) from top to bottom: $1353,1078,872,603,310,281,234,194,118,72$. 


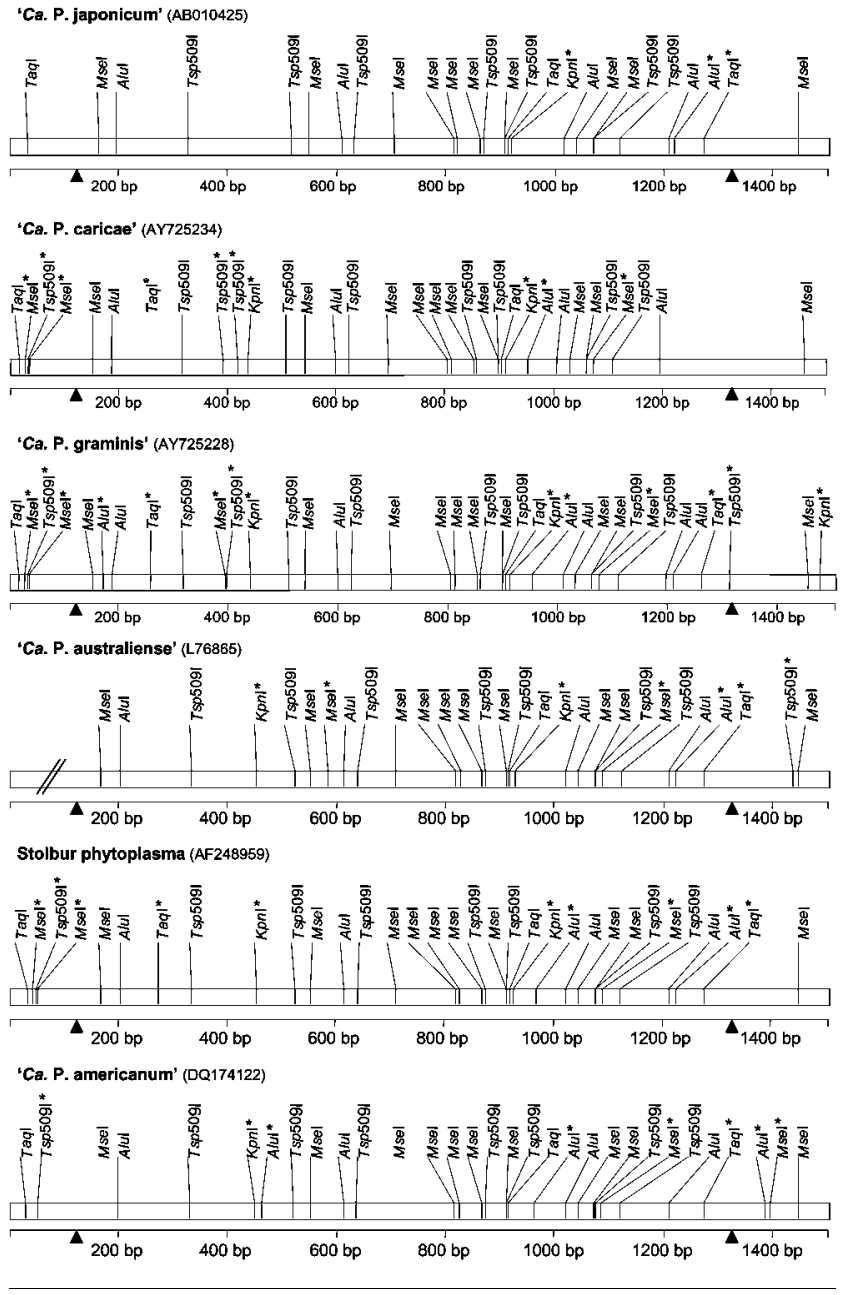

Fig. 2. Comparative analysis of putative restriction sites in $16 \mathrm{~S}$ rRNA gene sequences of stolbur phytoplasma and four 'Candidatus Phytoplasma' species most closely related to 'Ca. P. americanum'. Sequences were obtained from GenBank. All sequences are about $1.5 \mathrm{~kb}$ in length except ' $\mathrm{Ca}$. P. australiense', which is $1.33 \mathrm{~kb}$. Arrows indicate the region analysed by RFLP analyses in Fig. 1. The variable restriction sites among these six species are indicated by asterisks.

(Swofford, 2002). A. palmae ATCC $49389^{\mathrm{T}}$ was used as the outgroup to root the tree. Bootstrap analyses (1000 replicates) were performed to estimate the stability and support for the inferred clades.

Of the 20 samples collected from Texas and Nebraska, 16 samples tested positive for phytoplasma. RFLP analysis of the PCR-amplified 16S rRNA gene sequence from eight representative PPT-infected potato plant samples indicated that one, PPT3-TX, contained a phytoplasma belonging to subgroup A (16SrI-A) of the 'Candidatus Phytoplasma asteris' (aster yellows phytoplasma) group (16SrI) and that the seven other PPT plant samples, including 1833 \#6-TX, were associated with a novel phytoplasma related to, but distinct from, the stolbur phytoplasma strain Stolbur-Rus.
Putative RFLP analysis of cloned 16S rRNA genes was consistent with the results based on actual RFLP analyses. These seven closely related strains were further differentiated into two subgroups based on RFLP analysis using the restriction enzyme MseI (Fig. 1). Based on analysis of putative restriction maps of $16 \mathrm{~S}$ rRNA gene sequences using restriction enzymes AluI, KpnI, MseI, TaqI and Tsp509I, the novel PPT phytoplasma was readily differentiated from closely related phytoplasmas ('Candidatus Phytoplasma japonicum', 'Candidatus Phytoplasma caricae', 'Candidatus Phytoplasma graminis', 'Candidatus Phytoplasma australiense' and stolbur phytoplasma) (Fig. 2). The similarity coefficients of the RFLP patterns of the novel phytoplasma derived from putative restriction map analysis of $16 \mathrm{~S}$ rRNA gene sequences using 18 restriction enzymes (Lee et al., 1998) are $90 \%$ with stolbur phytoplasma, $88 \cdot 5 \%$ with 'Ca. P. japonicum', 89.6\% with ' $C a$. P. australiense', $85 \%$ with ' $C a$. P. caricae' and $85 \%$ with ' $C a$. P. graminis'. The novel PPT phytoplasma is termed American potato purple top wilt (APPTW) phytoplasma.

Comparative analysis of $16 \mathrm{~S}$ rRNA gene sequences revealed that the novel APPTW phytoplasma shared 96.6\% $16 \mathrm{~S}$ rRNA gene sequence similarity with stolbur phytoplasma, 96.2 \% with 'Ca. P. australiense', 95.8\% with 'Candidatus Phytoplasma fragariae', $95 \cdot 2 \%$ with bindweed yellows phytoplasma (IBS), 94.4\% with 'Ca. P. japonicum', $92 \cdot 7 \%$ with ' $C a$. P. graminis' and $91 \cdot 0 \%$ with ' $\mathrm{Ca}$. P. caricae'. Phylogenetic analysis using nearly full-length 16S rRNA gene sequences of nine representative phytoplasma strains associated with PPT-infected potato plants in Texas and Nebraska (shown in bold in Fig. 3), 24 ' $\mathrm{Ca}$. Phytoplasma' species, other phytoplasmas representing distinct phytoplasma groups or subgroups and $A$. palmae (as an outgroup) yielded four equally parsimonious trees. One of these trees is presented in Fig. 3. Three PPT phytoplasma strains (PPT3-TX, PPT4-TX and PPT14-NE2) were clustered with ' $C a$. P. asteris'. The other six novel APPTW strains (APPTW1-TX, APPTW2-TX, APPTW9-NE, APPTW10-NE, APPTW12-NE and APPTW13-NE) represented a distinct lineage within the expanded stolbur subclade that now includes stolbur phytoplasma (16SrXII-A), 'Ca. P. australiense' (16SrXII-B), 'Ca. P. japonicum', 'Ca. P. fragariae', IBS, 'Ca. P. caricae' (16SrXVII), 'Ca. P. graminis' (16SrXVI) and novel PPT phytoplasmas. Based on putative restriction map and phylogenetic analyses of $16 \mathrm{~S}$ rRNA gene sequences, the novel APPTW phytoplasma, 'Candidatus Phytoplasma americanum' is designated as a new 16S rRNA gene RFLP group, 16SrXVIII. Four strains, APPTW1-TX, APPTW2-TX, APPTW9-NE and APPTW12NE were designated as subgroup 16SrXVIII-A; three strains, APPTW 1883 \#6-TX, APPTW10-NE and APPTW13-NE were designated as subgroup 16SrXVIII-B.

16S rRNA gene sequence comparisons revealed that the novel APPTW phytoplasma shared $96.6 \%$ or less sequence similarity with 24 previously described ' $\mathrm{Ca}$. Phytoplasma' species and phytoplasma strains representing other 


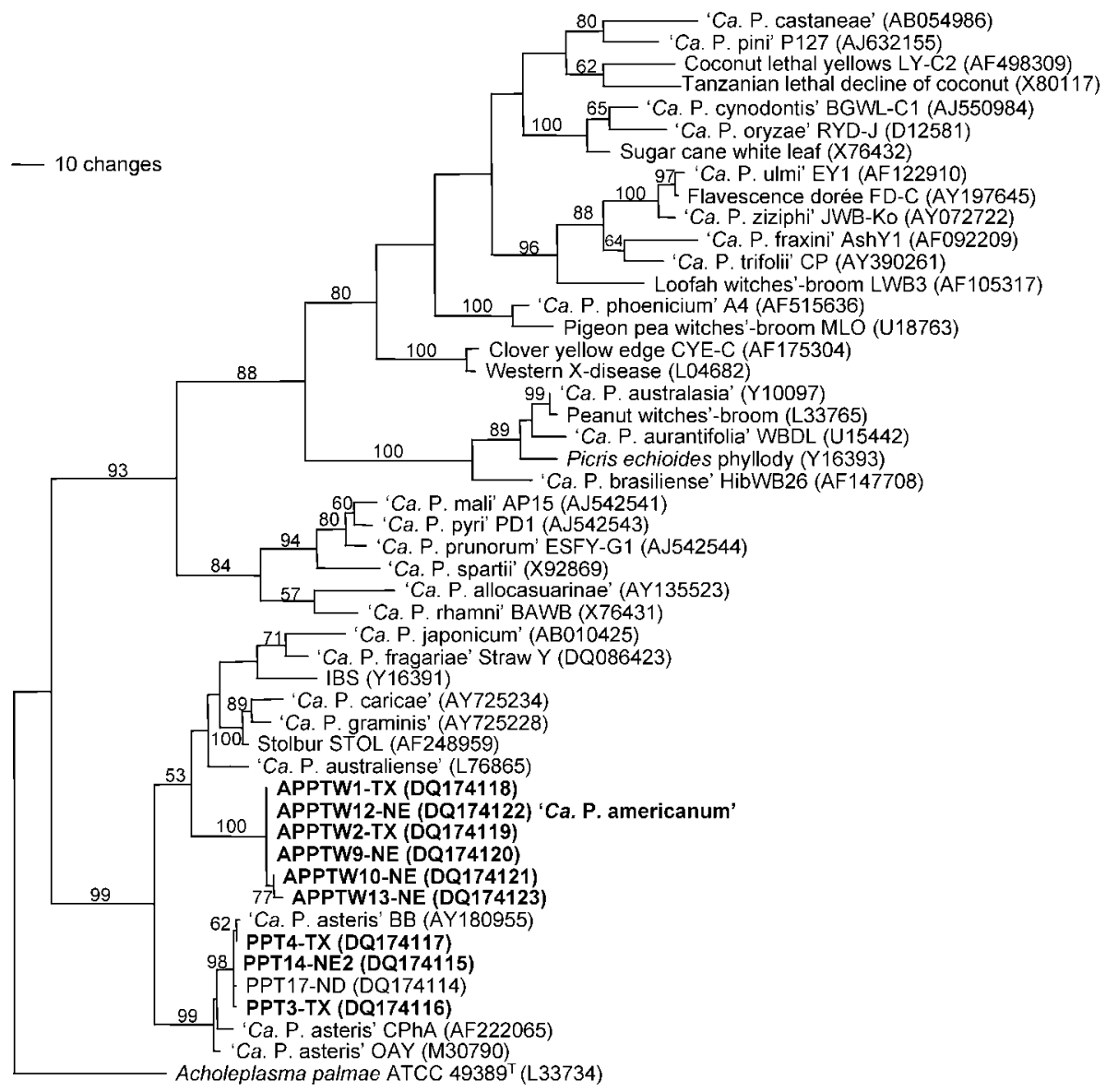

Fig. 3. Phylogenetic tree constructed by parsimony analysis of nearly full-length $16 \mathrm{~S}$ rRNA sequences from previously described 'Ca. Phytoplasma' species, representative phytoplasma strains from other 16Sr groups and representatives of the PPT strains, including the novel APPTW phytoplasma strains, detected in Texas (TX) and Nebraska (NE) (indicated in bold). Sequences were aligned using CLUSTAL V. A. palmae ATCC $49389^{\top}$ was used as the outgroup to root the tree. Branch lengths are proportional to the number of inferred character state transformations. Bootstrap values $>50 \%$ (measures of support for the inferred subclades) are shown on branches. GenBank accession numbers are given in parentheses. Bar, 10 inferred character state changes.

unnamed phytoplasma groups or subgroups. According to recommendations by the International Research Program for Comparative Mycoplasmology, Phytoplasma/ Spiroplasma Working Team - Phytoplasma Taxonomy Group (IRPCM, 2004), 'a 'Ca. Phytoplasma' species description should refer to a single, unique $16 \mathrm{~S}$ rRNA gene sequence ( $>1200 \mathrm{bp}$ )' and 'a strain can be recognized as a novel 'Ca. Phytoplasma' species if its 16S rRNA gene sequence has $<97.5 \%$ similarity to that of any previously described ' $C a$. Phytoplasma' species.' Results from the sequence and phylogenetic analyses conducted in this study support the recognition of the novel APPTW phytoplasma as a representative of a novel ' $\mathrm{Ca}$. Phytoplasma' species. On the basis of unique DNA and biological properties, we propose that the novel APPTW phytoplasma represents 'Candidatus Phytoplasma americanum', with strain APPTW12-NE as the reference strain.

\section{Description of 'Candidatus Phytoplasma americanum'}

'Candidatus Phytoplasma americanum' (a.mer.i.can'um. N.L. neut. adj. americanum pertaining to America).

APPTW12-NE is the reference strain. Related phytoplasma strains include APPTW1-TX, APPTW2-TX, APPTW9-NE, APPTW10-NE, APPTW13-NE and APPTW 1833 \#6-TX, which are associated with potatoes exhibiting purple top syndrome in Texas and Nebraska, USA.

'Candidatus Phytoplasma americanum' [(Mollicutes) NC; NA; O, wall-less; NAS (GenBank accession number DQ174122), oligonucleotide sequences of unique regions of the 16S rRNA gene are 5'-GTTTCTTCGGAAA-3' (68-80), $5^{\prime}$-GTTAGAAATGACT-3' (142-153) and 5' -GCTGGTGGCTT-3' (1438-1448); P (Solanum tuberosum, phloem); M]. 


\section{References}

Arocha, Y., López, M., Piñol, B., Fernández, M., Picornell, B., Almeida, R., Palenzuela, I., Wilson, M. R. \& Jones, P. (2005). 'Candidatus Phytoplasma graminis' and 'Candidatus Phytoplasma caricae', two novel phytoplasmas associated with diseases of sugarcane, weeds and papaya in Cuba. Int J Syst Evol Microbiol 55, 2451-2463.

Banttari, E. E., Orr, P. H. \& Preston, D. A. (1990). Purple top as a cause of potato chip discoloration. Trans ASAE 33, 221-226.

Green, M. J., Thompson, D. A. \& MacKenzie, D. J. (1999). Easy and efficient DNA extraction from woody plants for the detection of phytoplasmas by polymerase chain reaction. Plant Dis 83, 482-485.

Higgins, D. G. \& Sharp, P. M. (1989). Fast and sensitive multiple sequence alignments on a microcomputer. Comput Appl Biosci 5, 151-153.

IRPCM Phytoplasma/Spiroplasma Working Team - Phytoplasma Taxonomy Group (2004). 'Candidatus Phytoplasma', a taxon for the wall-less, non-helical prokaryotes that colonize plant phloem and insects. Int J Syst Evol Microbiol 54, 1243-1255.

Khadhair, A. H., Hiruki, C., Hwang, S. F. \& Wang, K. (1997). Molecular identification and relatedness of potato witches'-broom phytoplasma isolates from four potato cultivars. Microbiol Res 152, 281-286.

Lee, I.-M., Gundersen-Rindal, D. E., Davis, R. E. \& Bartoszyk, I. M. (1998). Revised classification scheme of phytoplasmas based on RFLP analyses of $16 \mathrm{~S}$ rRNA and ribosomal protein gene sequences. Int J Syst Bacteriol 48, 1153-1169.

Lee, I.-M., Davis, R. E. \& Gundersen-Rindal, D. E. (2000). Phytoplasma: phytopathogenic mollicutes. Annu Rev Microbiol 54, 221-255.
Lee, I.-M., Bottner, K. D., Munyaneza, J. E., Secor, G. A. \& Gudmestad, N. C. (2004a). Clover proliferation group (16SrVI) subgroup A (16SrVI-A) phytoplasma is a probable causal agent of potato purple top disease in Washington and Oregon. Plant Dis 88, 429.

Lee, I.-M., Martini, M., Marcone, C. \& Zhu, S. F. (2004b). Classification of phytoplasma strains in the elm yellows group (16SrV) and proposal of 'Candidatus Phytoplasma ulmi' for the phytoplasma associated with elm yellows. Int J Syst Evol Microbiol 54, 337-347.

Leyva-López, N. E., Ochoa-Sánchez, J. C., Leal-Klevezas, D. S. \& Martinez-Soriano, J. P. (2002). Multiple phytoplasmas associated with potato diseases in Mexico. Can J Microbiol 48, 1062-1068.

McCoy, R. E., Caudwell, A., Chang, C. J. \& 15 other authors (1989). Plant diseases associated with mycoplasma-like organisms. In The Mycoplasmas, vol. 5, pp. 545-560. Edited by R. F. Whitcomb \& J. G. Tully. New York: Academic Press.

Schneider, B., Seemüller, E., Smart, C. D. \& Kirkpatrick, B. C. (1995). Phylogenetic classification of plant pathogenic mycoplasmalike organisms or phytoplasmas. In Molecular and Diagnostic Procedures in Mycoplasmology, vol. 2, pp. 369-380. Edited by S. Razin \& J. G. Tully. San Diego, CA: Academic Press.

Secor, G. A., Lee, I.-M., Bottner, K. D., Rivera-Varas, V. \& Gudmestad, N. C. (2006). First report of a defect of processing potatoes in Texas and Nebraska associated with a new phytoplasma. Plant Dis 90, 377.

Swofford, D. L. (2002). PAUP*: Phylogenetic analysis using parsimony ( ${ }^{*}$ and other methods), version 4 . Sunderland, MA: Sinauer Associates.

Valiunas, D., Staniulis, J. \& Davis, R. E. (2006). 'Candidatus Phytoplasma fragariae', a novel phytoplasma taxon discovered in yellows diseased strawberry, Fragaria $\times$ ananassa. Int J Syst Evol Microbiol 56, 277-281. 